\title{
THE DIMENSIONS OF HAPPINESS WITHIN THE OXFORD HAPPINESS QUESTIONNAIRE: DEVELOPING A VALID MULTIDIMENSIONAL MEASUREMENT INSTRUMENT FOR A PORTUGUESE SAMPLE
}

\author{
Ana Galvão \\ Instituto Politécnico de Bragança, Campus de Santa Apolónia \\ Bragança \\ Saúl Neves de Jesus \\ Universidade do Algarve \\ Marco Pinheiro \\ Instituto Politécnico de Bragança, Campus de Santa Apolónia \\ Braganca \\ mpinheiro@ipb.pt \\ João Viseu \\ Universidade do Algarve
}

Recepción Artículo: 31 enero 2020

Admisión Evaluación: 4 marzo 2020

Informe Evaluador 1: 1 enero 2020

Informe Evaluador 2: 1 enero 2020

Aprobación Publicación: 20 abril 2020

\section{Compliance with ethical standards}

All ethical procedures were followed. Authorisation to distribute the questionnaire was given by the Conselho Coordenador dos Institutos Superiores Politécnicos, participants were informed about the objectives of the study, that their participation was voluntary, i.e. there were no rewards to participate, that the responses were anonymous (no email address was requested nor was it possible to leave any identifying comment or back-tracing of the respondents IP or MAC address), that participation could end whenever they desired, and that the data collected would serve solely and exclusively for the purposes of the research. No financing or compensation of any kind was received.

\section{ABSTRACT}

The evidence that individuals' happiness and general well-being are closely related has made happiness a frequently studied topic in the last decades. Studies showed that happiness has several dimensions and that these are dependent, amongst others, of cultural, economic, and social factors. The aim of this study was to validate a measure that identifies possible dimensions of happiness having as a starting point the Oxford Happiness Questionnaire. An online questionnaire with socio-professional items and the Oxford Happiness Questionnaire was used. A sample of 1032 individuals from several Portuguese higher education establishments was collected, of which 581 (56.3\%) were students, 257 (24.9\%) were faculty members, and 194 (18.8\%) were non-teaching 


\section{THE DIMENSIONS OF HAPPINESS WITHIN THE OXFORD HAPPINESS QUESTIONNAIRE: DEVELOPING A VALID MULTIDIMENSIONAL MEASUREMENT INSTRUMENT FOR A PORTUGUESE SAMPLE}

staff. The sample was divided into two subsamples: sample $1(n=508)$ and sample $2(n=524)$. A Principal Components Analysis (PCA) was performed on sample 1, followed by Covariance Based Structural Equation Modelling (CB-SEM) on sample 2. The PCA presented results, consistent with the existing theory, for a three-factor model. CB-SEM identified several items with significant correlations with more than one latent variable, which were eliminated from the model. A valid model ( $\mathrm{CFI}=.95 ; \mathrm{TLI}=.94 ; \mathrm{AGFI}=.95 ; \mathrm{RMSEA}=.04$ ) was obtained, with three dimensions: Joy (six items); Positivism (nine items); and Reliability (two items). We conclude that a threedimension model is valid for the population under study and should be applied to other populations to deepen the conclusions. These three dimensions may serve as a basis to better understand what influences our happiness and propose interventions to promote it.

Keywords: happiness; joy; positivism; reliability; higher education

\section{RESUMO}

As dimensões da felicidade dentro do questionário de felicidade Oxford: desenvolvimento de um instrument de medição multidimensional válido para uma amostra portuguesa. A evidência de que a felicidade e o bem-estar geral dos indivíduos estão intimamente relacionados fez da felicidade um tema frequentemente estudado nas últimas décadas. Estudos demonstraram que a felicidade tem várias dimensões e que estas dependem, entre outros, de factores culturais, económicos e sociais. 0 objectivo deste estudo foi validar uma medida que identifica possíveis dimensões da felicidade, tendo como ponto de partida 0 Questionário da Felicidade de Oxford. Foi utilizado um questionário online com itens socioprofissionais e o Questionário Oxford da Felicidade. Foi recolhida uma amostra de 1032 indivíduos de vários estabelecimentos de ensino superior portugueses, dos quais 581 (56,3\%) eram estudantes, 257 (24,9\%) eram docentes e 194 (18,8\%) eram pessoal não docente. A amostra foi dividida em duas subamostras: amostra 1 ( $n=508)$ e amostra 2 ( $n=524)$. Foi realizada uma Análise de Componentes Principais (APC) na amostra 1, seguida de Modelação da Equação Estrutural Baseada na Covariância (CB-SEM) na amostra 2. A APC apresentou resultados, consistentes com a teoria existente, para um modelo com três factores. A CB-SEM identificou vários itens com correlações significativas com mais do que uma variável latente, que foram eliminados do modelo. Foi obtido um modelo válido (CFI=.95; $\mathrm{TLI}=.94 ; \mathrm{AGFI=.95;}$ RMSEA=.04), com três dimensões: Alegria (seis itens); Positivismo (nove itens); e Fiabilidade (dois itens). Concluímos que um modelo tridimensional é válido para a população em estudo e deve ser aplicado a outras populações para aprofundar as conclusões. Estas três dimensões podem servir como base para compreender melhor o que influencia a nossa felicidade e propor intervenções para a promover.

Palavras-chave: felicidade; alegria; positivism; fiabilidade; educação superior

Throughout history philosophers have considered the pursuit of happiness the main motivation of human beings (Diener, 1984). The definition of happiness is a much older topic than the recent research on this construct, e.g. there is a vast and growing number of studies that seek to define it (Cipresso, Serino, \& Giuseppe, 2014; Liaghatdar, Jafari, Abedi, \& Samiee, 2008; Stewart, Watson, Clark, Ebmeier, \& Deary, 2010; Veenhoven, 2008). Nowadays, the approach to this concept has become a central topic for scholars and practitioners, as populations are taking more medication (e.g. antidepressants and antipsychotics) to fight mental health problems (e.g. stress, depression, anxiety, burnout).

The effect that happiness exerts on global well-being is widely studied (Cipresso et al., 2014; Veenhoven, 2008) and the pursuit of happiness has been a goal of mankind since the beginning of time, playing such an important role in our lives that even some of the most important moments in Human history include it as a common objective and a basic Human right:

We hold these truths to be self-evident, that all men are created equal, that they are endowed by their Creator with certain unalienable Rights, that among these are Life, Liberty and the pursuit of Happiness (Preamble to the Declaration of Independence of the United States of America - National Archives 2017).

In this study we focus on the definition of Hills and Argyle (2001) of happiness, thus a combination of relative existence of positive emotions, lack of negative emotions, and satisfaction with life, which finds correspondence in the items of the measurement instrument used. 
Specifically, the statements that there is still room for improvement in research methods and consequent modelling of the processes involved, drove our research to the objective to adapt and validate a measurement instrument, specifically for the Portuguese reality, that not only measures overall happiness but also certain dimensions of happiness. The importance of identifying possible dimensions of happiness will enable future studies of specific aspects of happiness on the one hand and, in particular cases, intervention on certain aspects of happiness that may fall short of the desired levels.

We believe that this study may contribute for a better understanding of happiness, in the Portuguese context, and that future studies, relying on this adapted and multidimensional scale, will help individuals and organisations to be more able to promote happiness and, therefore, contribute for increasing the overall well-being of the several stake-holders of those same organisations.

\section{THEORY}

Happiness, as a predominantly subjective concept, is difficult to define and much of the existing definitions do not gather consensus among experts. Notwithstanding this difficulty, two frameworks of happiness achieved consensus among scholars: the "bottom-up" approach, which views happiness as the combination of positive and negative feelings (Diener, 1984; Tellegen et al., 1988); and the "top-down" approach, , which suggests that happiness is primarily the product of an individual's cognitions. This means that individuals make subjective assessments about their experiences and, consequently, they evaluate if they are satisfied or not with their life (Diener, 1984). Regarding the bottom-up perspective, happiness is achieved by the immediate satisfaction of an individual's needs, failure to satisfy these needs will lead to unhappiness (Galinha \& Ribeiro, 2005). In turn, the topdown perspective refers to the satisfaction that an individual must feel in order to be happy (Galinha \& Ribeiro, 2005). According to this perspective, the relationship between satisfaction and happiness is conditioned by ambition, previous experiences, and by comparisons with other individuals (Galinha \& Ribeiro, 2005).

In essence, happiness is based on a subjective evaluation of one's life considering feelings and emotions. As such, this concept ,comparatively to subjective well-being (SWB), includes both life satisfaction ( im ek, 2009) and the quality of life (Diener, 2000; Shin \& Johnson, 1978). Furthermore, recent studies suggested that happiness is also influenced by welfare, opening a venue for a more universal acceptance of this concept (Medvedev, Shepherd, \& Hautus, 2015). That is, without welfare there is no happiness and vice versa.

Happiness can also be interpreted through the dichotomy of hedonism versus eudaimonism. The hedonic perspective of well-being aims to understand what life experiences are pleasurable, individuals must search for experiences that allow them to reach happiness. In opposition, the eudaimonic perspective puts happiness in second plan, not considering it as the main predictor of well-being. According this perspective, well-being would only be achieved when individuals performed activities that were fulfilling and that enabled them to reach their full potential (Kashdan et al. 2008; Ryan and Deci 2001). Taking these aspects into account, happiness is better understood from a hedonic point of view. As such, this concept, from an intellectual framework of well-being, can be described by constructive feelings ranging from gratification to intense joy, showing relative stability and consistency both over time and in various situations. Thus, happiness has affective and cognitive components, and these can be denominated, respectively "hedonic", that is, the pleasantness of the various situations that affect a person's experience, and "contentment", this being the degree to which an individual perceives that his or her life goals are met (Kumar, 2013).

We can thus say that, in psychology, happiness is recognized as an emotion, which can be positive or negative, and has an important effect on people's success. Happy people tend to have an optimistic attitude towards events, they are responsible, and tend to be more successful (Boehm \& Lyubomirsky, 2008). Psychologists believe that happiness has three main components: the relative existence of positive emotions, lack of negative emotions, and satisfaction with life (Hills \& Argyle, 2001).

Happiness is an important construct within positive psychology, and yet it is difficult to define and problematic to evaluate, although being a very important factor in human life. A happy person always has good feelings 


\section{THE DIMENSIONS OF HAPPINESS WITHIN THE OXFORD HAPPINESS QUESTIONNAIRE: DEVELOPING A VALID MULTIDIMENSIONAL MEASUREMENT INSTRUMENT FOR A PORTUGUESE SAMPLE}

about himself and others, discarding in this way desolation, accepting failures, never forgetting the lessons that life teaches him, is always honest with himself and with others, lives in the present, and is resilient when faced with problems (Bahrami, Rajaeepour, Rizi, Zahmatkesh, \& Nematolahi, 2011).

Seligman and Csikszentmihalyi (2000) were two fundamental authors for the rise of positive psychology, changing the existing paradigm focused on negative experiences, such as depression and stress, to a paradigm that emphasizes the role of positive experiences and psychological growth. These authors also made it possible to change the focus from cure to prevention and opened pathways to better understand well-being, as well as happiness in all aspects of life, including the fields organisational behaviour and organisational psychology.

Diener (2000) concluded that the lack of negative feelings and the existence of multiple pleasant feelings had a direct effect on one's well-being and that an excess of negative emotions, like depression or low self-esteem, influenced negatively life satisfaction and well-being. With this view on well-being and life satisfaction, more attention started to be given to the quality of life, i.e. the individual's personal assessment to determine whether life is worth being lived (Diener, 2000; Shin \& Johnson, 1978).

im ek (2009) defined subjective well-being as the individual's perception about his or her well-being, as a cognitive dimension, combining positive affects with a lack or very low levels of negative affects and life satisfaction. This means that subjective well-being is also affected by one's ability to evaluate his or her own life ( im ek, 2009).

These findings and definitions are closely tied to the concept of happiness, as Shin and Johnson (1978) concluded that quality of life can be evaluated through happiness.

But well-being, happiness or quality of life go well beyond the individual. They play an important role in and are simultaneously influenced by work and economic factors and, as such, influence society as a whole.

\section{HAPPINESS: ROLE AT THE WORKPLACE AND IN THE ECONOMY}

In 2014, a study of the European Agency for Safety and Health at Work underlined that perceived job insecurity, task organization, and number of working hours were responsible for a decrease in happiness at the workplace. This underlines the importance of considering the aspects that cause happiness at work and what are its consequences for workers and organisations (Fisher 2010).

Studies on happiness at the workplace have only recently been given more attention. The majority focused on the relationship between happiness and job satisfaction, work engagement, and job performance. These studies found clear evidences that happy workers perform better than less happy workers and even concluded that it is not success that makes individuals happy, it is their happiness that results in success. Also, it was observed that this construct fosters the physical and psychological health of workers, meaning that a happy worker will present desirable job attitudes (e.g. job satisfaction and organizational commitment) and work behaviors, as well as a better job performance (Fisher 2014). These studies followed earlier research in the field of positive psychology that concluded that individuals with more positive thoughts achieved a more optimal use of their brains, especially when compared to individuals with negative affects, e.g. stress, depression, or anxiety (Seligman \& Csikszentmihalyi, 2000).

Achor (2010), another author who studies happiness at the workplace, stated that $90 \%$ of an individual's happiness is determined by how one's brain views and processes the world and not by the outside world itself, thus emphasising the subjective nature of happiness. According to the same author, $75 \%$ of professional achievement and success is explained by the combination of an individual's levels of positivism, his or her ability to view success positively rather than as a threat, and the existence of a social environment that supports success, the remaining 25\% can be explained by the Intelligence Quotient (IQ) (Achor, 2010).

Organisations where joy, relaxation, and cheerfulness are present promote happiness and well-being and also productivity and improved performance (Rosenbluth \& Peters, 1992). Other studies concluded that positive feelings and affects improve intelligence, creativity, and an individual's overall energy. Also, the brain is more productive (Achor, 2012; Fischer, 2011). 
These several studies, evidencing the importance of happiness and positivism at the workplace as catalysts for success, followed the concept of flow, developed by Csikszentmihalyi (1975), defined as " the holistic sensation that people feel when they act with total involvement" ( $p$. 4). But flow on itself is not a synonym of happiness but rather a state of mind, or mood, when performing tasks, that can lead to happiness, when the status of flow is reached. According to Csikszentmihalyi $(1975,1990,1996)$, there are eight states of being (Activation, Flow, Control, Relaxation, Boredom, Apathy, Worry, and Anxiety), and flow is only achieved when one's abilities and challenges are at their maximum.

Another area where happiness and well-being are a topic of study and discussion is economics. Although the combination of economics and happiness may seem, to say the least, awkward to the public in general, and almost suggests that happiness can be calculated in an analytical manner, truth is that research on the economics of happiness has excelled in the last decade and economists all around the world are giving increasing importance to this topic (Mackerron, 2012). Happiness, or well-being, is not new to economics. Actually, the "father" of economic theory, Adam Smith, in his revolutionary "An Enquiry into the Nature and Causes of the Wealth of Nations", normally referred to in short as "The Wealth of Nations" (Smith, 1776), already proposed that the well-being of consumers was more important than production, thus introducing well-being in economic theory since its inception (Dalziel et al., 2018; Smith, 1776).

Although the definitions of happiness or well-being, which in the economics of happiness are used interchangeably, are not consensual, we believe the five broad accounts of well-being, as described by Dolan et al. (2006), are the ones that best describe the concepts of well-being and happiness in an economists point of view. These five accounts are:

(1) preference satisfaction, in which well-being consists in the freedom and resources to meet one's own wants and desires; (2) objective lists (or basic needs), in which well-being is the fulfillment of a fixed set of material, psychological and social needs, which are identified exogenously; (3) flourishing (or eudaimonic), in which wellbeing means the realization of one's potential, along dimensions such as autonomy, personal growth, or positive relatedness; (4) hedonic (or affective), in which wellbeing is synonymous with positive affect balance, a relative predominance of positive moods and feelings; and (5) evaluative (or cognitive), in which wellbeing is the individual's own assessment of his or her life according to some positive criterion (p. 706).

But when we talk about the economics of happiness, most probably the generally best known example is Bhutan's Gross National Happiness index which is considered more important in this country than the Gross National Product - GNP (Bates, 2009). This concept that happiness is more important than the GNP has evolved in such a manner and has gained so many supporters, that in 2019 the $7^{\text {th }}$ World Happiness Report has been produced to support the United Nations High Council (Helliwell, Layard, \& Sachs, 2019). This report uses six key variables to assess happiness together with indices for positive and negative affects. The six key variables are: GDP per capita; Social support; Healthy life expectancy at birth; Freedom to make life choices; Generosity; and Perceptions of corruption (Helliwell et al., 2019). As can be seen from this list of key variables, they represent a mix of economy, politics, and personality traits, taking, thus, a holistic view on happiness and how it can be measured on a country-level. According to this perspective, a study of Diener et al. (2010) observed that income is related with the well-being levels of individuals. For example, the authors registered the existence of a statistically significant relationship, although modest, between income and positive/negative affects. This research also demonstrated the relevance of societal income, individuals considered central to their life satisfaction to live in an economically developed country (Diener et al. 2010).

Notwithstanding this evolution from a strict economic point of view to a more holistic point of view, wellbeing, life satisfaction, quality of life, and ultimately happiness, continue to be multidimensional concepts, which are difficult to compile in one simple measurement standard and the psychological side of happiness, namely the one derived from positive and negative affects, continues to play a central role (Diener, 2000).

But how can we measure happiness and how can we account for cultural differences between populations? 


\section{THE DIMENSIONS OF HAPPINESS WITHIN THE OXFORD HAPPINESS QUESTIONNAIRE: DEVELOPING A VALID MULTIDIMENSIONAL MEASUREMENT INSTRUMENT FOR A PORTUGUESE SAMPLE}

Within a broad and diffuse literature, the Oxford Happiness Inventory emerged in the late 1980s as an important contribution to both defining and assessing happiness (Robbins, Francis, \& Edwards, 2010). The inventory was later changed to the Oxford Happiness Questionnaire by the original authors (Hills \& Argyle, 2002), starting to measure happiness in a one-dimensional manner.

However, several authors argued that happiness encompasses different dimensions, such as:

i. the frequency and magnitude of positive affect or joy;

ii. the average level of satisfaction over a period of time;

iii. the absence of negative feelings (Argyle \& Crossland, 1987); and also,

iv. satisfaction with life;

v. self-esteem; and

vi. joy (Liaghatdar et al., 2008).

Presently, it is possible, in particular through psychophysiology, to measure with great accuracy and objectivity, the experiences perceived by individuals. However, there is still room for improvement in research methods and the consequent modelling of the processes involved, to define a state of happiness (Cipresso et al., 2014; Liaghatdar et al., 2008).

\section{MATERIAL AND METHODS}

\section{Participants}

A questionnaire in electronic format, produced using Google Forms, was distributed, with the assistance of the Conselho Coordenador dos Institutos Superiores Politécnicos (Coordinating Council of the Polytechnic Higher Institutes), the overseeing body of the Polytechnic higher education institutions in Portugal, to a total of eleven Portuguese public higher education institutions, covering all of Portugal's regions. Within each institution the link to the questionnaire was sent to the general email address, thus reaching all staff and students. A total of 1032 respondents, between faculty, support staff, and students, participated in the study. Of these respondents, 273 were of the male gender and 759 of the female gender. Relatively to the professional or student status of the respondents, 257 were faculty members, 194 were support staff, and 581 were students. Finally, in what concerns relationship status, 594 were single, 350 married or living in a stable relationship, 74 divorced and 14 widowers.

For the purposes of this study, the original database was randomly divided into two samples, using the functionality of the IBM SPSS software, originating in: sample 1, with a total of 508 participants, and sample 2, with a total of 524 participants.

\section{Ethical procedures}

All ethical procedures according to the Declaration of Helsinki (World Medical Association, 2013) were followed. Authorisation to distribute the questionnaire was given by the Conselho Coordenador dos Institutos Superiores Politécnicos, participants were informed about the objectives of the study, that their participation was voluntary, i.e. there were no rewards to participate, that the responses were anonymous (no email address was requested nor was it possible to leave any identifying comment or back-tracing of the respondents IP or MAC address), that participation could end whenever they desired, and that the data collected would serve solely and exclusively for the purposes of the research.

\section{Measures and Variables}

As data collection instrument an online questionnaire was used, composed by two parts. The first part with sociodemographic and professional questions: higher education institution, gender, age, relationship status, nationality, type of course (for the students only), name of the course (for the students only), year of the course (for the students only), place of residence, hobbies, area of teaching (for the faculty only) and if they were members of the permanent staff of the institution or temporary staff (for faculty and non-faculty staff members only). 
In the second part of the questionnaire the Oxford Happiness Questionnaire - $\mathrm{OHQ}$ (Hills \& Argyle, 2002) in its Portuguese version (Cunha et al., 2018) was presented.

The Oxford Happiness Questionnaire was used as the starting point of our research, as it has been used in Portugal for several years already, showing good psychometric properties (Cunha et al., 2018; Mamedes, 2009), and therefore considered as one of the best measurement instruments for happiness. The questionnaire is derived from the Oxford Happiness Inventory (Hills \& Argyle, 2001), which on its turn builds on the design and format of the Beck Depression Inventory (Beck, Ward, Mendelson, Mock, \& Erbauch, 1961).

The $\mathrm{OHQ}$ is a unidimensional self-report questionnaire with 29 statements using a six-point Likert scale ranging from "strongly disagree" to "strongly agree" (Hills \& Argyle, 2002). Reliability values of this questionnaire are considered high $(\mathrm{a}=.91)$.

\section{Data Analysis}

To achieve the objective of this study, we performed our analysis in two phases. In the first phase, we performed an Exploratory Factor Analysis through Principal Components Analysis (PCA) with Varimax Rotation in IBM SPSS version 23 on the data from sample 1, to investigate if dimension reduction of the $\mathrm{OHQ}$ was possible at all and if the found dimensions (or factors or components), showed any adherence to the theoretical constructs. Only items with factor loadings equal or larger than .40 and components with an Eigen-value of 1 or higher were included in the analysis. For the Kaiser-Meyer-Olkin (KMO) test we followed Kaiser's recommendations where results between .90 and 1.00 are considered "marvellous" (Kaiser, 1974)

Still in this first phase, the grouping suggested by the PCA was presented to a focus group of nine individuals who had to answer if, for every statement of the 29 items, they agreed with the assigned Portuguese word, of between joy, positivism, and reliability.

In the second phase, we performed a Confirmatory Factor Analysis through Covariance Based Structural Equation Modelling (CB-SEM) in IBM AMOS version 22 on the data of sample 2, using the division of items by the three factors that emerged from the PCA performed in phase 1.

The estimation method used in all model testing was maximum likelihood, and normalised scores were produced. The fit of the estimated models was assessed using the following fit-indices: Chi-squared/degrees of freedom ( $\mathrm{c}^{2} / \mathrm{df}$ ), Comparative Fit Index (CFI), Tucker-Lewis index (TLI), Adjusted Goodness of Fit Index (AGFI), and Root Mean Square Error of Approximation (RMSEA). As cut-off for these indices we used the following recommendations: $\mathrm{c}^{2} / \mathrm{df}<5$ (Schumacker \& Lomax, 2004), CFI $\geq .90, \mathrm{TLI} \geq 0.95, \mathrm{AGFI} \geq .90$ and RMSEA $<.08$ (Parry, 2017)

Important to note is that the objective was never to develop a happiness measurement scale from scratch, but rather use an existing instrument that has proven its reliability over the years, the Oxford Happiness Questionnaire (Hills \& Argyle, 2002). Therefore, the main goals defined were: (1) identify the possible dimensions of happiness with a valid relationship between statistical grouping and underlying theoretical construct; and (2) reach satisfactory goodness of fit of the new model.

\section{RESULTS}

\section{Descriptive and Correlational Results}

As a preamble of our model validation exercise, we needed to confirm if our two samples, as previously described, could be considered similar in statistical terms. For this purpose, we first calculated the mean scores and respective standard deviations on the $\mathrm{OHQ}$ for both samples. The results are presented in Table 1. 
THE DIMENSIONS OF HAPPINESS WITHIN THE OXFORD HAPPINESS QUESTIONNAIRE:

DEVELOPING A VALID MULTIDIMENSIONAL MEASUREMENT INSTRUMENT FOR A PORTUGUESE SAMPLE

Table 1 - Mean (M) and standard deviation (SD) for the Oxford Happiness Questionnaire, per sample

\begin{tabular}{llll}
\hline \hline & $\mathrm{n}$ & $\mathrm{M}$ & $\mathrm{SD}$ \\
\hline Sample 1 & 508 & 3.91 & .598 \\
Sample 2 & 524 & 3.92 & .617 \\
Total & 1,032 & 3.92 & .607 \\
\hline \hline
\end{tabular}

As can be seen from the data presented in Table 1, both samples present very similar mean scores and standard deviations, giving us a piece of the first evidence that the random sampling had produced two similar groups.

Secondly, we analysed if there were statistically significant differences between both samples, in what concerns their mean scores on the $\mathrm{OHQ}$. The performed t-test for independent samples, did not reject the null hypothesis $(p=.830)$, evidencing that there were no statistically significant differences between both samples.

\section{Exploratory Factor Analysis}

After having performed the previously described steps, we were in a position to start the first phase of our model adaptation and validation exercise through Exploratory Factor Analysis. For this, a Principal Component Analysis (PCA) with Varimax Rotation was performed, to uncover the underlying structure of the data. We restricted the analysis to components with an Eigenvalue of 1 or higher and items with factor loadings of .40 or higher.

We first checked whether the sample was adequate for a PCA using the Kaiser-Meyer-0lkin (KMO) test which in our sample resulted in a score of .933, meaning that it was adequate for a PCA.

In our first simulation, we did not restrict the number of components, obtaining a five-component structure. However, after analysing these first results, we concluded that the way items were grouped did not adhere to any possible theoretical, or even logical, construct. The same type of results was obtained with a forced four-component model. However, restricting the model to three components brought us to a structure that logically grouped the items but also, and more importantly, in a way that adhered to the underlying theoretical constructs. The results of this three-component model are shown in Table 2. 
Table 2 - Principal Component Analysis loading factors for the three-component model

\begin{tabular}{|c|c|c|c|}
\hline & \multicolumn{3}{|c|}{ Component } \\
\hline & 1 & 2 & 3 \\
\hline OHQ15 & .764 & & \\
\hline OHQ9 & .723 & & \\
\hline OHQ22 & .649 & & \\
\hline OHQ11 & .642 & & \\
\hline OHQ16 & .640 & & \\
\hline OHQ3 & .577 & & \\
\hline OHQ17 & .572 & & \\
\hline OHQ12 & .556 & & \\
\hline OHQ7 & .540 & & \\
\hline OHQ18 & .526 & & \\
\hline OHQ20 & .495 & & .447 \\
\hline OHQ19 & & .662 & \\
\hline OHQ24 & & .654 & \\
\hline OHQ6 & & .651 & \\
\hline OHQ28 & & .625 & \\
\hline OHQ27 & & .590 & \\
\hline OHQ1 & & .570 & \\
\hline OHQ10 & & .568 & \\
\hline OHQ13 & & .550 & \\
\hline OHQ14 & & .545 & \\
\hline OHQ29 & & .504 & \\
\hline OHQ23 & & .480 & \\
\hline OHQ5 & & .444 & \\
\hline OHQ2 & & & .682 \\
\hline OHQ4 & & & .680 \\
\hline OHQ21 & & & .522 \\
\hline OHQ26 & .475 & & .482 \\
\hline OHQ25 & & & .474 \\
\hline OHQ8 & .413 & & .455 \\
\hline Eigenvalue & 7.58 & 3.47 & 1.25 \\
\hline$\%$ of variance & 26.12 & 11.95 & 4.30 \\
\hline Cronbach $\alpha$ & .876 & .820 & .722 \\
\hline
\end{tabular}

Even though items $\mathrm{OHQ8}, \mathrm{OHQ20}$, and $\mathrm{OHQ} 26$ loaded to more than one component, it was decided to maintain these items as the three of them were consistent with the underlying theoretical construct when included in the component where the items showed the highest loading factor.

From the data presented in Table 2, we can observe that $42.37 \%$ of the total variance is explained by these components and that the Cronbach's Alpha of the three components showed a good internal consistency meeting Nunnally's and Bernstein's (1994) criterion for acceptable internal consistency (Cronbach's $\alpha \geq .70$ ).

The research team, after analysing each of the statements in each component, defined the first component or dimension as "joy", the second one as "positivism", and the third one as "reliability". As direct translations can 


\section{THE DIMENSIONS OF HAPPINESS WITHIN THE OXFORD HAPPINESS QUESTIONNAIRE: DEVELOPING A VALID MULTIDIMENSIONAL MEASUREMENT INSTRUMENT FOR A PORTUGUESE SAMPLE}

be misleading, the Portuguese word for reliability is also understood as "giving us confidence", "making one believe" or "rest assuring".

This grouping of items along the three components was presented to a focus group of nine people who had to answer if, for every statement of the 29 items, they agreed with the Portuguese word, of between joy, positivism, and reliability, that was chosen to describe each item. For each item, at least seven respondents agreed with the choice the research team had made. Given these results, we considered the obtained model suitable for the second phase of the analysis.

\section{Confirmatory Factor Analysis}

For the second phase of our model adaptation and validation exercise, we performed a Confirmatory Factor Analysis through Covariance Based Structural Equation Modelling (CB-SEM) methods. We used the maximumlikelihood estimation method through the software IBM AMOS version 22 and analysed the three-component model that was suggested in the previous phase, which grouped items to the traits: Joy; Positivism; and Reliability. For this step, we used sample 2, our cross-validating sample, as data source.

The initial 29 item model did not present a good fit $\left(\chi^{2} / \mathrm{df}=2,50 ; \mathrm{CFI}=.89 ; \mathrm{TLI}=.88 ; \mathrm{AGFI}=.88\right.$; RMSEA $=.053$ ), with several items presenting low regression weights with their respective latent variable. After simulating several alternatives and eliminating 12 items with regression weights below .40 and correlating the residuals e8 and e9, and e14 and e16, a 17-item model, presenting a good model fit and adherence to the theoretical construct was obtained, of which the path diagram is depicted in Figure 1.

Figure 1 - Path diagram of the 17-item model (standardised path coefficients) with the three dimensions of happiness (Sample 2; $n=524$ )

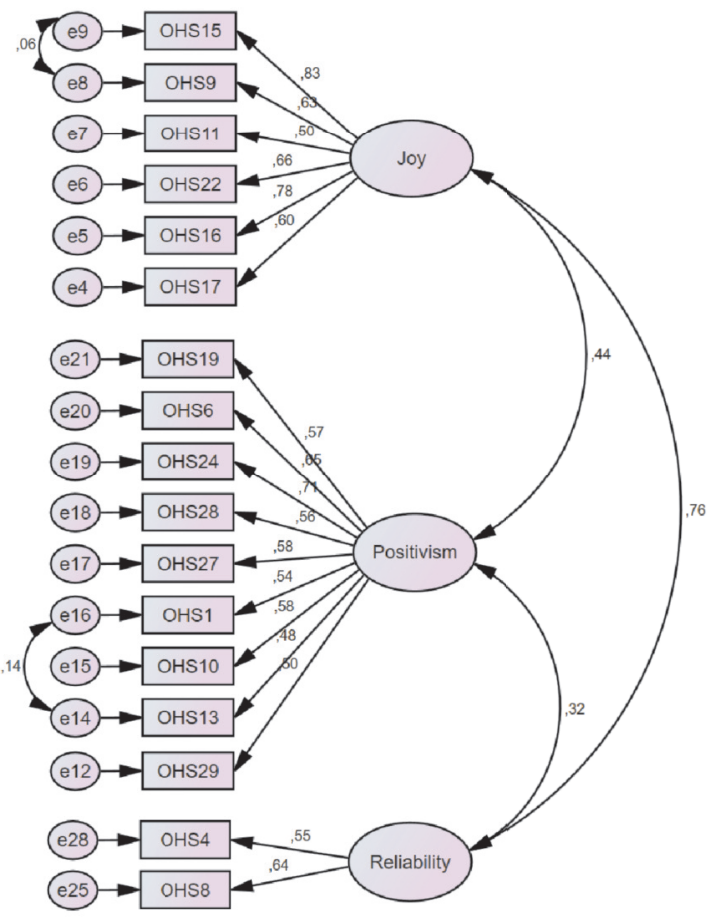


We verified the goodness of fit of this 17 item-model, as depicted in Figure 1, using the following fit-indices: Chi-squared/degrees of freedom $\left(\chi^{2} / \mathrm{df}\right)$, Comparative Fit Index (CFI), Tucker-Lewis index (TLI), Adjusted Goodness of Fit Index (AGFI), and, Root Mean Square Error of Approximation (RMSEA), taking into account the cut-off criteria presented in the data analysis section, being the results of these presented in Table 3.

Table 3 - Model fit indices

\begin{tabular}{llllll}
\hline \hline$\chi^{2} / \mathrm{df}$ & $\mathrm{df}$ & CFI & TLI & AGFI & RMSEA \\
\hline 2.24 & 114 & .94 & .93 & .93 & .049 \\
\hline \hline
\end{tabular} \\ $\mathbf{X} 2$ = chi-squared, $\mathbf{d f}=$ degrees of freedom, $\mathrm{CFI}=$ comparative fit index, TLI=Tucker-Lewis index, AGFI=Adjusted Goodness of Fit Index, RMSEA=root mean square error of approximation}

Based on these results we can state that our model presents a good fit, and is, therefore, suitable to test the three identified dimensions of happiness for similar samples.

\section{DISCUSSION AND CONCLUSIONS}

With our research we were able to adapt the Oxford Happiness Questionnaire to a multidimensional measurement scale, specifically adapted to a Portuguese sample. Our research was performed considering the cultural differences that define happiness, well-being, and life satisfaction and, thus, the need to have a very critical view on which measurement instruments to use in each culture. We strongly believe that our 17-item model measuring joy, positivism, and reliability, is not only statistically valid for this specific sample, but above all, valid in terms of the underlying psychological constructs. We acknowledge the limitation of having used only samples with individuals from higher education institutions - faculty, non-faculty support staff, and students - which may not be considered a valid sample for the whole Portuguese population. We can also not ignore the fact that the subjective nature of happiness may return biased results when only applying self-report instruments (Veenhoven, 2008), and therefore will proceed our research by comparing our scale with other self-report scales, but also with more objective measurement instruments.

We believe that this study, together with the new scale, will be a good starting point to measure happiness in its various dimensions in Portugal and that research with this scale should be expanded to other groups of the Portuguese population. One of the contexts that interests us to study is the business context, that is, to study the effect of happiness on productivity. The concept of organisational happiness is relatively recent and, therefore, often confused with motivation in a professional context, commitment or organisational commitment. However, the concept of organisational happiness is broader and includes several dimensions such as professional involvement with the organisation and function, job satisfaction, and positive commitment to the organisation and function. Organisational happiness thus arises from an affective commitment to the organisation, well-being in the organisation and function, and job satisfaction. In an unstable world, happiness has been increasingly distinguished as a main objective in the lives of employees and also in the existence of organisations. Given the aforementioned, our scale can be a valid instrument for studying organisational happiness.

This study has some limitations worth considering. Firstly, we used a sample composed by a higher education institutions population, not considering other professional occupations. This aspect may have skewed the obtained results. Also, we did not test other types of validity, for example factorial, discriminant, and criterion. Future studies should correct this gap, especially if we consider the subjective nature of happiness. It is vital to understand how happiness can be distinguished from other constructs with a positive nature and what outcomes can this concept predict. Another limitation concerns the way data was collected, on a single occasion, which increases the likelihood of common-method variance. In the future more, robust research designs should be 


\section{THE DIMENSIONS OF HAPPINESS WITHIN THE OXFORD HAPPINESS QUESTIONNAIRE: DEVELOPING A VALID MULTIDIMENSIONAL MEASUREMENT INSTRUMENT FOR A PORTUGUESE SAMPLE}

employed, especially to observe how happiness varies according to the different circumstances of an individual's experience.

Much attention has been paid in recent decades to the way happiness develops and is maintained in individuals and there is a growing concern by organisations and countries to better understand and facilitate its development in pursuit of promoting more sustained welfare.

As we have been able to present throughout this article, happiness is not only difficult to measure but also difficult to define, but given its importance for the Human kind, research on this topic should continue and specifically the underlying reasons that contribute to happiness should be better identified so that all parties - politics, education, organisations, health services- are able to take their decisions based on sound foundations and ultimately improve overall well-being.

\section{BIBLIOGRAPHIC REFERENCES}

Achor, S. (2010). The Happiness Advantage: The seven principles of positive psychology that fuel success and performance at work. New York, NY, US: Crown Business/Random House.

Achor, S. (2012). Positive Intelligence. Harvard Business Review, 90(1/2), 100-102.

Argyle, M., \& Crossland, J. (1987). The dimensions of positive emotions. British Journal of Social Psychology, 26(2), 127-137. https://doi.org/10.1111/j.2044-8309.1987.tb00773.x

Bahrami, S., Rajaeepour, S., Rizi, H. A., Zahmatkesh, M., \& Nematolahi, Z. (2011). The relationship between students' study habits, happiness and depression. Iranian Journal of Nursing and Midwifery Research, 16(3), 217-221.

Bates, W. (2009). Gross national happiness. Asian-Pacific Economic Literature, 23(2), 1-16. https://doi.org/10.1111/j.1467-8411.2009.01235.x

Beck, A. T., Ward, C. H., Mendelson, M., Mock, J., \& Erbauch, J. (1961). An inventory for measuring depression. Archives of General Psychiatry, 4, 561-571.

Boehm, J. K., \& Lyubomirsky, S. (2008). Does happiness promote career success? Journal of Career Assessment, 16(1), 101-116. https://doi.org/10.1177/1069072707308140

Cipresso, P., Serino, S., \& Giuseppe, R. (2014). The pursuit of happiness measurement: A psychometric model based on psychophysiological correlates. Scientific World Journal, 2014. https://doi.org/10.1155/2014/139128

Csikszentmihalyi, M. (1975). Beyond boredom and anxiety: Experiencing flow in work and play. London: JosseyBass.

Csikszentmihalyi, M. (1990). Flow: The psychology of optimal experience. New York: Harper Collins.

Csikszentmihalyi, M. (1996). Flow and the psychology of discovery and invention. New York: Harper Collins.

Cunha, S., Gama, C., Fevereiro, M., Vasconcelos, A., Sousa, S., Neves, A. C., ... Firmino-Machado, J. (2018). A felicidade e 0 engagement no trabalho nos cuidados de saúde primários. Revista Portuguesa de Medicina Geral e Familiar, 34, 26-32.

Dalziel, P., Saunders, C., Saunders, J., Bache, I., Scott, K., \& Allin, P. (2018). Wellbeing Economics: The Capabilities Approach to Prosperity and Policy. Cham, Switzerland: Palgrave Macmillan.

Diener, E. (1984). Subjective Well-Being. Psychological Bulletin, 95(3), 542-575.

Diener, E. (2000). Subjective well-being: The science of happiness and a proposal for a national index. American Psychologist, 55(1), 34-43. https://doi.org/10.1037/0003-066X.55.1.34

Dolan, P., Peasgood, T., \& White, M. (2006). Review of research on the influences on personal well-being and application to policy making. London.

Fischer, J. A. (2011). Accounting for Unobserved Country Heterogeneity in Happiness Research: Country Fixed Effects versus Region Fixed Effect. Munich Personal RePEc Archive, (22272), 6-25.

Galinha, I., \& Ribeiro, J. L. P. (2005). História e evolução do conceito de bem-estar subjectivo. Psicologia, Saúde \& Doenças, 6(2), 203-214. 
Helliwell, J. F., Layard, R., \& Sachs, J. D. (2019). World Happiness Report.

Hills, P., \& Argyle, M. (2001). Happiness, introversion-extraversion and happy introverts. Personality and Individual Differences, 30(4), 595-608. https://doi.org/10.1016/S0191-8869(00)00058-1

Hills, P., \& Argyle, M. (2002). The Oxford Happiness Questionnaire: A compact scale for the measurement of psychological well-being. Personality and Individual Differences, 33(7), 1073-1082. https://doi.org/10.1016/S0191-8869(01)00213-6

Kaiser, H. F. (1974). An index of factorial simplicity. Psychometrika, 39(1), 31-36. https://doi.org/10.1007/BF02291575

Kumar, D. (2013). The Relation of Stressful Life Events and a Happy Life. International Journal of Social Science \& Interdisciplinary Research, 2(2), 213-219.

Liaghatdar, M. J., Jafari, E., Abedi, M. R., \& Samiee, F. (2008). Reliability and Validity of the Oxford Happiness Inventory among University Students in Iran. The Spanish Journal of Psychology, 11(01), 310-313. https://doi.org/10.1017/S1138741600004340

Mackerron, G. (2012). Happiness economics from 35000 feet. Journal of Economic Surveys, 26(4), 705-735. https://doi.org/10.1111/j.1467-6419.2010.00672.x

Mamedes, A. K. P. (2009). Exploração psicométrica da versão portuguesa do oxford happiness questionnaire na população Angolana e posterior comparação com a população portuguesa (Tese de Mestrado). Lisboa: Instituto Superior de Psicologia Aplicada.

Medvedev, 0., Shepherd, D., \& Hautus, M. J. (2015). The restorative potential of soundscapes: A physiological investigation. Applied Acoustics, 96, 20-26. https://doi.org/10.1016/j.apacoust.2015.03.004

National Archives. (2017). The Declaration of Independence I National Archives. Retrieved June 12, 2019, from https://www.archives.gov/founding-docs/declaration

Nunnally, J. C., \& Bernstein, I. H. (1994). Psychometric Theory. McGraw-Hill, New York (Vol. 3).

Parry, S. (2017). Fit Statistics commonly reported for CFA and SEM. Cornell Statistical Consulting Unit (Vol. 08).

Robbins, M., Francis, L. J., \& Edwards, B. (2010). Happiness as stable extraversion: Internal consistency reliability and construct validity of the Oxford Happiness Questionnaire among undergraduate students. Current Psychology, 29(2), 89-94. https://doi.org/10.1007/s12144-010-9076-8

Rosenbluth, H. F., \& Peters, D. M. (1992). The customer comes second: Put your people first and watch. New York, NY: Harper Business.

Schumacker, R., \& Lomax, R. (2004). A beginner's guide to structural equation modeling (Oxford Psy). Oxford, England.

Seligman, M. E. P., \& Csikszentmihalyi, M. (2000). Positive psychology: An introduction. American Psychologist, $55(1), 5-14$.

Shin, D., \& Johnson, D. M. (1978). Avowed Happiness as an overall assessment. Social Indicators Research, 5 , 475-492.

im ek, Ö. F. (2009). Happiness revisited: Ontological well-being as a theory-based construct of subjective wellbeing. Journal of Happiness Studies, 10(5), 505-522. https://doi.org/10.1007/s10902-008-9105-6

Smith, A. (1776). An Enquiry into the Nature and Causes of the Wealth of Nations, 2 vols. London.

Stewart, M. E., Watson, R., Clark, A., Ebmeier, K. P., \& Deary, I. J. (2010). A hierarchy of happiness? Mokken scaling analysis of the Oxford Happiness Inventory. Personality and Individual Differences, 48(7), 845-848. https://doi.org/10.1016/j.paid.2010.02.011

Tellegen, A., Lykken, D. T., Bouchard, T. J., Wilcox, K. J., Segal, N. L., \& Rich, S. (1988). Personality similarity in twins reared apart and together. Journal of Personality and Social Psychology, 54(6), 1031-1039. https://doi.org/10.1037/0022-3514.54.6.1031

Veenhoven, R. (2008). Healthy happiness: Effects of happiness on physical health and the consequences for preventive health care. Journal of Happiness Studies, 9(3), 449-469. 
THE DIMENSIONS OF HAPPINESS WITHIN THE OXFORD HAPPINESS QUESTIONNAIRE:

DEVELOPING A VALID MULTIDIMENSIONAL MEASUREMENT INSTRUMENT FOR A PORTUGUESE SAMPLE

World Medical Association. (2013). World Medical Association Declaration of Helsinki Ethical Principles for Medical Research Involving Human Subjects. World Medical Association. https://doi.org/10.3917/jib.151.0124 